\title{
Method for Expressing Public Opinions Concerning the Introduction of an Emerging Technology to Society
}

\author{
Satoshi Yamamoto Non-member (Osaka University, yamamoto@nishilab.sys.es.osaka-u.ac.jp) \\ Kyoko Ito Non-member (Osaka University, ito@es.osaka-u.ac.jp) \\ Satoshi Ohnishi Non-member (Osaka University, ohnishi@nishilab.sys.es.osaka-u.ac.jp) \\ Shogo Nishida Fellow (Osaka University, nishida@, es.osaka-u.ac.jp)
}

Keywords : emerging technology, introduce in society, public spirit, internet, expressing opinion

In recent years, technology has undergone rapid development, its social impact has become very large. New technology that differs from existing technology dramatically and pervades society is called emerging technology. The practical introduction in the real world of emerging technology requires the understanding of a lot of people. Therefore, for the smooth introduction of emerging technologies in society, it is necessary to take into consideration the opinion of the general public. Methods of expressing opinion in a distributed environment are made available by the spread of the Internet. However, it is hard to get reliable opinions by in such as environment. Generally, opinion with public spirit is needed. There are differences in opinions according to the method of expressing them. However the general public inherently has public spirit. The focus of this study is finding a method to activate this public spirit.

A lot of methods of expressing opinions are based on the process of obtaining knowledge. In this study, this process is provided before expressing opinion. Internet is an interactive media, and it offers many methods to express opinion communicating with others. However, to communicate about emerging technology is a hard task for the general public, so the general public is less likely to have an opinion on the emerging technology.

While communicating directly with other people, they are likely to accept the opinions of others and give up their own thinking quite easily. Therefore, a method is necessary that would allow them to express their own opinions while being aware of the opinions of others, but without having to rely on them.

Schwarz's theory of public spirit is called norm activate theory. It states awareness of the need for altruistic behavior (awareness of consequence) activates awareness of responsibility to have an

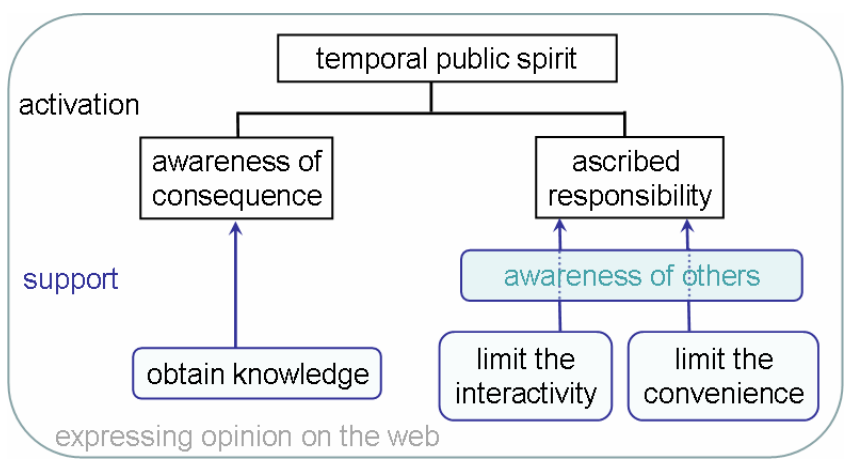

Fig. 1. Concept of activating public spirit. altruistic behavior (ascribed responsibility), and also the awareness of having to do altruistic behavior (moral). The method to activate "awareness of consequence" and "ascribed responsibility" has been considered based on the above-mentioned theory. If the general public obtains enough knowledge about emerging technology, they will recognize its social effects. Thus awareness of consequence is activated.

Generally, opinion expressed in face-to-face environment is more reliable than opinion expressed in distributed environment. Clear progression and facilitators make the difference. Thus, the convenience of a distributed environment negatively affects people's attitude. Therefore, we propose a method that will limit the convenience and which is closer to face-to-face environment. Also, the interactivity of the distributed environment is limited. That is, the burden is suppressed and opinions can be expressed freely by restricting direct communication. However, the participants will have knowledge about the opinions of others without communicating directly. Thus, awareness of the existence of others and their opinions is provided, and ascribed responsibility is activated. (Figure. 1)

The general public lacks the knowledge and finds it hard to form opinions about emerging technology. Therefore, it is necessary to help them clarify their thoughts. If examples are available, they could think analytically, but in the case of emerging technology, that is not possible. They will be able to have their own opinions if they are presented a life situation. Using hints from gaming techniques, we have divided the process of expressing opinion into two levels. The process of expressing opinion consists of determining whether the participants agree or disagree, and of describing the reason for their decision. The proposed method is implemented as a distributed system.

In our experiments, we observed that the proposed method enables the participants to express opinion with public spirit. Using the proposed method, participants expressed opinions about emerging technology, evaluation was conducted. Each group had five members; eighteen groups participated in the experiment. The participants were 90 men and women aged 20-59. They filled in questionnaires before and after the experiment. The answers to the questions were mainly on a Likert scale of seven. The theme selected for expressing opinions was one pertaining of the emerging technologies:Radio Frequency Identification technology.

The results of the experiment show that limiting interactivity and convenience is effective. In addition, the proposed method which refers to obtaining knowledge as a whole helped the general public express opinions with more ease. 


\title{
萌芽的科学技術の社会導入に向けた 公共心を有する意見表明手法の提案
}

\author{
非会員 山本 怜* 非会員 伊藤 京子**,* \\ 非会員 大西 智士* フェロー 西田 正吾*
}

\author{
Method for Expressing Public Opinions Concerning the Introduction of an Emerging \\ Technology to Society \\ Satoshi Yamamoto*, Non-member, Kyoko Ito**,*, Non-member, Satoshi Ohnishi*, Non-member, \\ Shogo Nishida*, Fellow
}

\begin{abstract}
Emerging technology may have considerable social impact. Because emerging technology has not yet been introduced in society, it is needed general public express its opinions on emerging technology. It is important that expressing opinion must have social spirit. A method to limit facility of the Internet and activate social spirit is proposed. Evaluation experiment were conducted to test the effectiveness of the proposed method, and the participant could express opinion with social spirit.
\end{abstract}

キーワード：萌芽的科学技術, 社会導入, 公共心, インターネット, 意見表明

Keywords: emerging technology, introduce in society, public spirit, internet, expressing opinion

\section{1. はじめに}

近年，科学技術は急激な発展を遂げており，社会に与え る影響は非常に大きくなっている。社会の中に広く浸透し, 確定的な位置を占める既存の科学技術とは異なる新規の先 端技術は，萌芽的科学技術 (emerging technology) と呼ば れ，ユビキタス技術などが一例として挙げられる(1)。萌芽 的科学技術は, 実験・研究を進める中で, 社会の一部とし て多くの人が意識する技術となるため, 実社会での実用的 な導入・利用には多くの人の理解が求められる。萌芽的科 学技術の円滑な社会導入に向けて, 専門家ではない一般の 人々の意見を取り入れることが求められる。政府が『科学 技術の振興に関する施策の総合的かつ計画的な推進を図る ため』に策定している科学技術基本計画でも, 一般の人々 の意見取得の必要性が記されている(2)。科学技術に限らず, 政治などの様々な社会的意思決定に一般の人々が参加する プロセスや手法は市民参加型手法と呼ばれる ${ }^{(3)}$ 。

\footnotetext{
* 大阪大学基礎工学研究科

干 560-8531 大阪府豊中市待兼山町 1-3

Graduate School of Engineering Science, Osaka University

1-3, Matikaneyama-cho, Toyonaka, Osaka 560-8531

** 大阪大学コミュニケーションデザイン・センター

干 560-0043 大阪府豊中市待兼山町 1-16

Center for the Study of Communication-Design, Osaka University

1-16, Matikaneyama-cho, Toyonaka, Osaka 560-0043
}

現在参加型手法の法整備は進められており, 一般の人々 が意見を表明する機会は増加している(3)。特に，インター ネットの普及により分散環境下で行う意見表明が利用され るようになっている。例えば, 行政手続法で規定されてい るパブリックコメント（社会的意思決定に際し，意見を公 募する制度）が行政ポータルサイト e-Gov や各省庁のホー ムページから行えるようになっている ${ }^{(4)}$ 。分散環境の利点 として時間的・空間的制約からの解放や容易性などの利便 性がある(5)。さらに, インターネットは双方向性を有して おり，他者とコミュニケーションを取り合うことができる。 そして, 対面と比べて匿名性の確保が容易であり, 大量の 意見を効率的に処理可能である ${ }^{(6)}$ 。これらの利点は, 様々 な立場の人から大量の意見を取得することが求められる萌 芽的科学技術にとって有益である。一方で, 公機関が実施 している公聴会などの意見表明の場とは異なり, 分散環境 が人に対して与える影響などへの検討が不十分であり，信 頼に足る意見の取得が難しいといわれている(5)。自宅など リラックスできる環境で行う意見表明は，柔軟な意見表明 が可能であると同時に, 不実な姿勢で行う危険性を有して いる。一般に，意見表明手法で求められる意見は，公的な 意識を持って考えられた比較的理性的な公論といわれてい るが(7) (8), 手法次第で得られる意見に差異が生じる ${ }^{(9)}$ 。例 えば，パブリックコメントでは，世論調査などと比べると， 自由な意見が得られるといわれる。ここで, 萌芽的科学技 術のような複雑な問題に関して, 一般の人々に自由に意見 
を表明してもらうことは容易ではない。良く分からない， 馴染みのないものに対しては，否定的な印象を持ちやすく， 短絡的に否定するなど公的な意識を発揮しにくいと考えら れるからである。しかし，一般の人々は本来的に公的な意 識を備えており，その意識を活性化する方法を取ることが

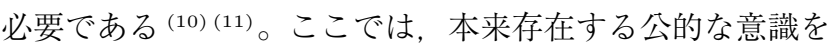
引き出すことを「活性化」と呼称する。すなわち，単純に 一般の人々の意見を取り入れようとするだけでは不十分で あり，一般の人々の心理面を考慮して，意見表明の方法を 検討する必要がある。

以上より本研究では，公的な意識という観点から，一般 の人々の心理面を考慮した分散型の意見表明手法が必要と 考える。本研究では, 萌芽的科学技術の実社会での導入 利用に向けて，一般の人々が本来持つ公的な意識を活性化 させ，意見を表明できるように，心理面を考慮した手法を 提案する。本論文の流れは，まず公的な意識を活性化する 方法の検討と提案する意見表明手法について述べる。そし て, 提案手法のシステム化に関して, 設計や開発方法を述 べる。最後に，システムを利用した評価実験の方法と結果 について述へ，それにもとづく考察を述べる。

\section{2. 公共心を有する意見の表明手法の提案}

本章では，公的な意識を持って意見表明を行うための手 法を検討する。まず，公的な意識を活性化する方法を検討 し，それを意見表明に適用する方法を検討する。

$\langle\mathbf{2} \cdot \mathbf{1}\rangle$ 意見表明における公共心 $\quad$ 人の公的な意識を 活性化する必要性は，様々な分野で主張されている。心理 学の分野では，社会的意思決定に人々が参加するには，個々 人が利已的な意識ではなく「社会の眼」を持つことが必要 と主張されている(11)。また，社会心理学の分野では，環境 問題などの多くの社会的問題は，私的・短期的な利益の追 求と社会的・長期的な利益の損出という社会的ジレンマの 枠組みで捉えられ，その解決には個々人の「利他的行動」 が必要とされている ${ }^{(12)}$ 。公的な意識を有する意見表明は, 自己の利益だけを考えないという意識から生じる利他的行 動に繋がるものであり，利他的行動が起こる要因は「公共 心」である ${ }^{(10)}$ 。以上より，意見表明時に求められる公的な 意識を「公共心」と考える。公共心の概念は文化や時代に よって異なるが，ここでは，自分を含む集団や社会の事情 や状況を考慮する心情と定義できる ${ }^{(13)}$ 。本研究に打いて は，萌芽的科学技術が自分と社会にもたらす影響を鑑みた 意見表明を行おうとする姿勢となる。

\section{$\langle 2 \cdot 2\rangle$ 公共心を有する意見表明手法の検討}

$\langle 2 \cdot 2 \cdot 1\rangle$ 萌芽的科学技術に対する意見表明の特徴 般の人々の意見表明という観点から見ると，萌芽的科学技 術には以下の特徴がある。萌芽的科学技術は日常的に触れ る機会がなく，関心を持ちにくい。さらに，意見表明の前提 となる意見や知識が欠けている可能性が高く，実際に意見 を表明した経験がある人は多くない。そして，他者がどの ような意見を持っているか把握している可能性も低い (14)。
関心も知識もない状態では，意見表明に真摰に取り組む ことは困難であると考えられる。また，実社会の人々の意 見は，本来他者との相互作用を通して形成されるものであ り，他者の意見を知る機会を持つことが望まれる ${ }^{(15)}$ 。しか し，他者と意見を交わす機会があっても，一般の人々にとっ て難解な話題では，日常的な話題と異なり，他者と意見を 交わすこと自体が負担となり得る ${ }^{(8)}$ 。ここで，一般の人々 に求められるのは合意形成ではなく意見表明であり，最終 的な意思決定は意思決定者が行う。そのため, 参加者間で 直接コミュニケーションを行い，議論を収束させることは 必ずしも必要ではない。また，一般の人々は萌芽的科学技 術に関して元々意見を持っている可能性が低い。そのため, 他者と直接コミュニケーションをとることで，他者の意見 に依存してしまい，自分で考えることを放棄する可能性が 考えられる。萌芽的科学技術に関する意見表明には，これ らの問題の解決が必要である。

$\langle 2 \cdot 2 \cdot 2\rangle$ 公共心活性化の方針 多くの意見表明手法 に打いて, 判断材料として情報を提供し, 知識を獲得して もらうプロセスが存在する ${ }^{(3)}$ 。公共事業などの従来の事例 では，実際に対面している事例や類似事例を提示すること で，知識を獲得させる方法が現在行われている ${ }^{(22)}$ 。これに より，不確定な部分や考え，イメージを明確化させること ができる。本研究においても，意見表明に先んじて知識の 獲得プロセスを設けることとする。このとき，提供する情 報によって特定の考えや結論への誘導が起こる可能性があ る。そのため, 適切な知識獲得のために, 利害関係のない 専門家が選定した知識や事例の提供を行うのが適当である と考えられる。萌芽的科学技術の場合は, 実例が存在しな い可能性があるので，導入実験や導入が予定される事例に 関する情報を提供することが考えられる。

利他的な意識に関する理論に Schwarz の規範活性化理論 がある ${ }^{(16)}$ 。規範活性化理論は, 利他的行動が実行される心 理過程を記述する理論である。すなわち，利他的行動が必 要であるという意識（重要性認知）から, 利他的行動を行 うのは自分の責任であるという意識（責任感）が活性化さ れ，さらに利他的行動を行うべきであるという意識（道徳 意識）が活性化され，そこから利他的行動が起こるという 理論である。これは，利他的行動を取ろうとする意識，す なわち公共心が生じるプロセスを段階的に記述している。 本研究の目的は公共心を有する意見を得ることにあり，一 般の人々に恒常的な公共心を持ってもらうことではない。 また，恒常的な公共心を持つことは容易ではない。そこで, 公共心を活性化する最低限の要因のみに焦点を当て，意見 表明を行う間のみ，一時的に公共心を活性化させることを 考える。すなわち, 「重要性認知」と「責任感」を一時的に 活性化させることを目指す。

$\langle 2 \cdot 2 \cdot 3\rangle$ 公共心の活性化手法 重要性認知は, 利他 的行動が必要とされる問題が存在することを認知すること である。萌芽的科学技術に関する知識獲得が適切に行われ たとすれば，その社会的な影響の大きさ等について認知で 
きる。それにより，重要性認知を得ることが可能と考えら れる。

次に，責任感は，利他的行動を行うという自分の責任を 意識することである。一般に，分散環境の場合と比べ，公 機関が開催する公聴会などの意見表明の場で得られる意見 の信頼性は高い。公聴会などの意見表明の場には，明確な 進行の枠組みやファシリテータの存在などがある。分散環 境の利便性の高さが意見表明を行う人々の取り組む姿勢に 影響を与えていると考える。そこで，いつでも，どこでも 自由な形式で行えるという利便性の高さを制限し，公的な 意見表明の場に近づけることとする。

また，公的な意見表明の場で意見表明を行う場合，その 意見はその場にいる専門家やその他の一般の人々の目に唒 されることを意味する。一方，分散環境にも双方向性があ り，揭示板など他者とのコミュニケーションを取りつつ意 見表明を行う手法が多く存在する。しかし，対面環境と比 べ，表明した意見が他者に評価される感覚は高くない。特 に匿名性が担保されている場合は，それが顕著である。す なわち，他者の存在の位置づけや他者とのコミュニケーショ ンの取り方に差異がある。また，責任感の活性化を妨げる 要因として，個人の行動の有効性に疑問を感じる可能性が ある (17)。その解決には，情報提供法（他者の行動に関する 情報を提供する）が有効である(12)。すなわち，他者の考え 方を知ることが必要となる。しかし，〈2・2・1〉で述べたよう に, 萌芽的科学技術ではコミュニケーション自体が障害と なり得る。

以上から，双方向性をある程度制限した上で，他者の存 在を意識し，自分が表明した意見が他者の目に触れること を意識でき，さらに，他者の考え方を知ることができるが， その意見に依存することないような環境が必要である。そ こで，意見表明と他者とのコミュニケーションを完全に別 プロセスとして扱うことを考える。そのために，進行プロ セスをコントロールし，決まった手順で意見表明やコミュ ニケーションを行うようにする。具体的には，各プロセス に制限時間を設けることで，進行の夕イミングやコミュニ ケーションを統制する。直接的に意見をやりとりすること はないが，他者の意見を知ることで，自分以外の他者が自 分と一緒に意見表明を行っていることを意識できると考え られる。同時に，直接的なコミュニケーションがないため， 負担を抑制でき，自分の考えを表明できると考えられる。

以上の手法により, 重要性認知と責任感に働きかけ, 活 性化させることで，顕在化されているか否か分からない公 共心を活性化させ，公共心を有する意見表明を可能にする。 Fig.1 は公共心の活性化のコンセプト図を示す。知識を獲 得 (obtain knowledge) により重要性認知（awareness of consequence) が活性化され，双方向性の制限（limit the interactivity）と利便性の制限（limit the convenience）に より他者の存在（awareness of others）が意識され責任感 (ascribed responsibility) が活性化される。

$\langle 2 \cdot 3\rangle$ 意見表明手法の提案 以上の公共心の活性化手

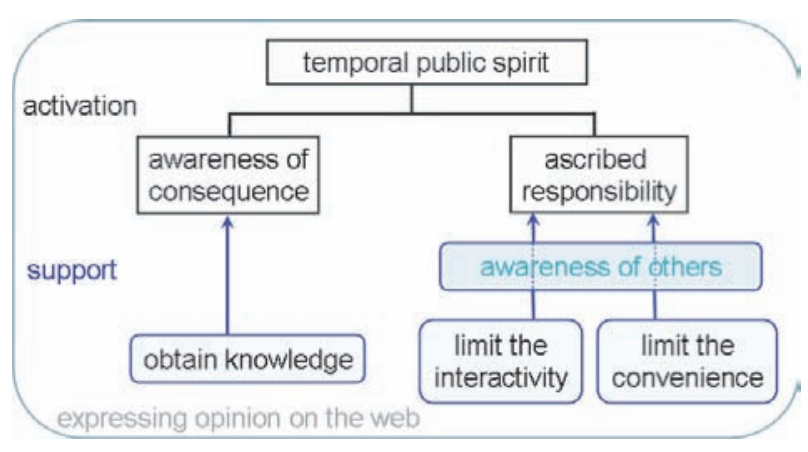

Fig. 1. Concept of activating public spirit.

法を，意見表明手法として実現させるとき，以下のような 要素が必要となる。まず，意見表明者が知識を獲得するた めの情報提供が必要となる。次に，他者の存在や意見を意 識し，また自分の意見が他者に知られる感覚を持ってもら うために，他者と同時に意見表明に取り組む枠組みと他者 の意見を知る機会が必要となる。そして他者の意見を知る 機会は，意見表明とは別のプロセスとして行われる必要が ある。最後に，以上のようなプロセスの進行を実現し，か つ自由な意見表明への参加を制限するために，制限時間を 設ける必要がある。すなわち，(1) 情報提供が行われた上 で，(2) 意見表明と他者の意見を知ることが別プロセスと して行われ，(3) それらのプロセスの進行が制限時間によ り統制される枓組みに，(4) 複数人が同時に取り組むよう な意見表明手法を提案する。

以上の提案手法では，公共心という心理的な要因から意 見表明手法を検討している。しかし，〈2・2・1〉で述べたよう に, 多くの一般の人々は萌芽的科学技術の意見や知識に欠 け，意見を表明した経験もない。そのため，仮に公共心が 活性化されたとしても，自分の考えをまとめ適当な形で表 明できるとは限らない。そこで，意見表明に際して，意見 の表明自体をサポートすることも必要となる。

意見表明に先んじて知識を獲得するが，発展過程にある 萌芽的科学技術の場合, 従来の問題とは異なり, 実例が少 なく，過去の問題や経験から分析的に考えることができな い。そこで，ある程度直感的に意見を表明できるようにす る。また，一般の人々が非日常的なテーマに関して，自由 に意見を表明することは難しい (9)。そこで，知識の獲得と 同様に実社会での導入 ・利用の事例を問題設定として揭げ, それを考えの軸として，意見を表明するという形式をとる。 イメージを持ちやすく, 実際の利害を感じられる具体的な 場面を問題設定として提示し，ある程度分析的に自分の意 見を持てるようにする。複数の具体的な事例を提示し，意 見表明と他者の意見を知るプロセスを事例ごとに繰り返す ようにする。それらの問題設定に対し，一問一答形式で賛 成か反対かを判断し，その判断の裏にある考えを判断理由 として自由記述するという流れを用いる。この場合，賛成 か反対という二択を最初に行うので，直感的に意見を表明 しやすい。さらに，賛成か反対という 2 值のデー夕は，機 械的に処理しやすいため，意見を効率的に活用することに 
も繋がる可能性がある。以降では,「意見」とは賛成・反対 の判断と判断理由を合わせたものと考える。

$\langle 2 \cdot 4\rangle$ 関連研究 社会問題の解消に心理的アプロー チから取り組んでいる研究には，以下のようなものがある。 久郷ら (18) は，高レベル放射性廃棄物問題の主体的なリス クコミュニケーションを行うために，思考・内省を促すシ ステムを開発している。この研究はコンテンツの内容に重 点を置いているが，本研究では他者との関係に重点を置い た手法を提案している。谷口ら(19) は，利他的行動の心理 プロセスにおいて重要な役割を果たす道徳意識に着目し, その階層構造モデルを提案し，検証を行っている。その結 果，道德意識が階層的に活性化していく可能性などを確認 し，提案モデルの妥当性を理論的に支持している。しかし， このモデルを活用した手法の提案は行っていない。

科学技術と社会導入に関する研究には, 以下のような研 究がある。中川 ${ }^{(20)}$ は, ナノテクノロジーの性質を明らか にし，既存の問題分析方法で，ナノテクノロジーを扱うの は難しいと指摘している。そして，この問題を分析するた めの新たな手法として，技術的側面と社会的価值の側面か ら問題を構造化する手法を提案している。しかし, 問題の 構造化以降の発展性に関しては未知である。太田ら ${ }^{(21)}$ は, 新奇性の高い環境技術を社会に導入する際の戦略を提示す ることを目的に，具体的な事例を用いて検討を行っている。 分野横断的ネットワークと公共的企業家機能の役割と特性 を検証した結果，政策プロセスにおいてはこれらの要因が 社会導入の鍵になることを明らかにしている。しかし，特 定事例に関する実験的実施であり，汎用性は確認できてい ない。

\section{3. 意見表明システムの設計・開発}

本章では， 2 章で提案した意見表明手法をシステムとし て実現するために，設計・開発を行う。

$\langle\mathbf{3} \cdot \mathbf{1}\rangle$ 必要機能 意見表明手法を分散型システムと して実装する。以下の機能がシステムに必要となる。

(a) 情報提供

知識獲得を行うための情報提供機能 $(\langle 2 \cdot 3\rangle$ の $(1))$ 。

（b）意見表明・閲覧機能（賛成·反対の判断，判断理由） 自分の意見を表明し，他者の意見を知るための機能 $(\langle 2 \cdot 3\rangle$ の $(2)$ )。意見には賛成・ ·対の判断と判断理由の 2 種類 がある。

(c) 複数ユーザ間の同期

提案手法の各プロセスの進行を制限時間により統制し $(\langle 2 \cdot 3\rangle$ の $(3))$, 複数のユーザが同時に提案手法を実施す るための機能 $(\langle 2 \cdot 3\rangle$ の $(4))$ 。

$\langle 3 \cdot 2\rangle$ 設 計 まず， (a) 情報提供の実現方法を考 える。インターネットを用いる基本的な知識獲得方法には, Web ページにアクセスしテキスト形式で知識を獲得してい く方法などがある。ここでは，全てのユーザが適度な負荷 で適切な知識獲得を行えるように，動画とスライドを用い た情報を用意し，それをユーザに提供する形式で行う。 次に，(b) 意見表明・閲覧機能と (c) 複数ユーザ間の同 期は，クライアント・サーバシステムを用いて実現させる。 1 台のサーバに複数人のユーザがアクセスし，各ユーザが ウェブブラウザから意見表明や他者の意見の閲覧を行う。 上述の動画とスライドもサーバにアクセスし, 取得するよ うにする。意見表明は，具体的な導入・利用事例に関する 質問文と賛成・ 対の選択肢を提示し, 賛否を選択した後, テキストボックスに判断理由を記述できるようにする。こ うして得た意見をデータベースに登録し，意見表明プロセ ス終了後に，同時に意見表明を行う全ユーザ分の意見を提 示する。さらに，ユーザ間の同期はサーバサイドから制限 時間を用いて各ユーザ間で進行のタイミングを合わせるこ とで実現させる。制限時間だけで，完全な統制を取ること は困難であるので，各ユーザの現在のプロセス情報を取得 し，全ユーザが意見表明を終えない限り，次のプロセスに は移らないような形式をとり，個人で自由に進行できない ようにする。

また，同時に意見表明を行うユーザの人数を決定する。 参加型手法における多人数の参加は受動的になるとされて おり，実際のワークショップなどでも 1 グループ 5 人程度 で行われている ${ }^{(23)}$ 。そこで, 暫定的に 1 グループ 5 人と してシステムを開発し, 予備実験を行い正式な人数を決定 する。上述の各プロセスの制限時間も同様に決定する。

以上より，具体的なモジュールは，情報や得られた意見を ユーザに提示するモジュール (provide), ユーザが表明し た意見を取得するモジュール (acquire)，ユーザ間の同期を 取るモジュール (synchronize) となる。これらのモジュー ルとデータベース及びユーザとの間のデータフローを Fig.2 に示す。図中の矢印はデータの流れを示す。サーバサイド のデータベースには，(a)のための動画とスライド (lecture movie and slide), (b) と (c)のための具体的な導入事例に 関する質問（question about actual example）と表明され た意見（Yes or No, reason for the decision）を格納する。 動画とスライド，質問を提示モジュールによりクライアン トサイドのウェブブラウザ上に表示する。質問に対する賛 成・反対と判断理由を取得モジュールにより取得しデータ ベースに格納する。これらのデータを提示モジュールによ りブラウザ上に表示するが，その際にユーザ間の同期をと り，全ユーザの意見表明が終わっていることを確認する。

〈3・3〉開 発 複数人のユーザが各自のパソコンを 用い, サーバに同時にアクセスして意見表明を行うように した。ウェブサーバとして Tomcat6.0.18を，データベー スサーバとして MySQL6.0を使用した。サーバサイドは JAVA を用い, クライアントサイドは OS やブラウザに依 存しないように, FLASH を用いて実装した。ブラウザ上に swf ファイルを表示し, Flash Player でページを閲覧でき るようにした。Flash Player は多くのパソコンに標準的に 用意されているため, 特殊なソフトのインストールの必要 がなく, パソコンに関する詳しい知識を必要としない。さら に, 全体の操作を容易にするため, 文字入力以外はマウス 


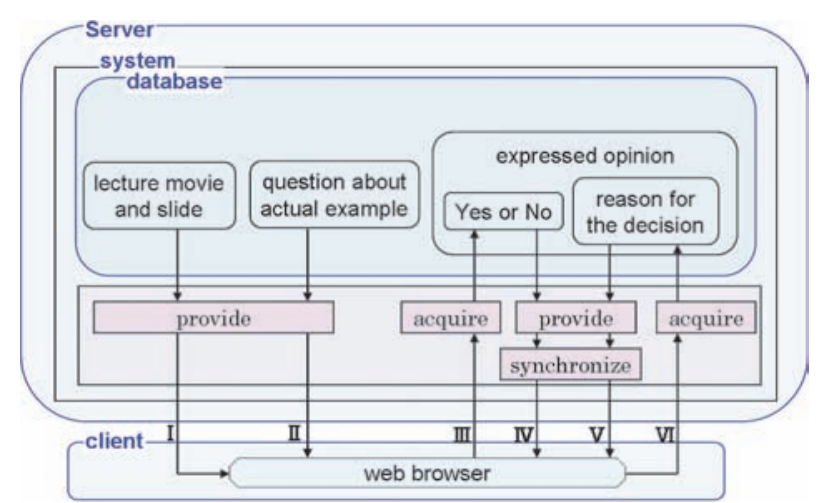

Fig. 2. Software configuration.

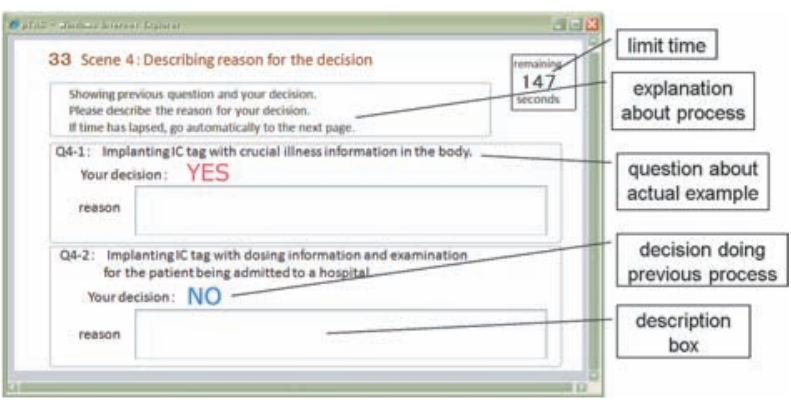

Fig. 3. Screen for describing the reason for the decisions.

のみで操作するようにした。OS は Windows XP，ブラウ ザは Internet Explorer7 と FireFox3 で動作確認を行った。

$\langle 3 \cdot 4\rangle$ 利用方法 システム全体は，以下の流机を複数 人で同時に行うものとなる。システム画面を Fig. 3, Fig.4 に示す。Fig.3は判断理由の記述画面, Fig.4 は判断理由閲 覧画面である。Fig.3では，上部に画面の説明，その下に 質問文及び前のプロセスで行った賛成・反対の判断，判断 理由を記述する領域が表示される。また，左上に制限時間 が表示される。Fig.4では，上部に質問文，左部に各ユー ザを表すアイコンが表示され，各ユーザの記述した判断理 由が一覧表示される。

(1) 知識獲得 (Fig.2 の I)

(2）導入事例に関する質問（Fig.2の II）

（3） 賛成・反対の判断（Fig.2の III）

（4）他者の判断を閲覧（Fig.2の IV）

(5) 判断理由の記述（Fig.2のVI, Fig.3)

（6）他者の判断理由を閲覧（Fig.2のV, Fig.4）

\section{4. 意見表明システムの評価実験}

本章では評価実験について述べる。実際にシステムを用 い，実験参加者に萌芽的科学技術に関する意見表明を行っ てもらい，提案した意見表明手法により，一般の人々が公 共心を有する意見表明を行えるようになるかを評価するこ とが目的となる。

\section{$\langle 4 \cdot 1\rangle \quad$ 実験方法}

$\langle\mathbf{4} \cdot \mathbf{1} \cdot \mathbf{1}\rangle$ 意見表明のテーマ 萌芽的科学技術の中から テーマを選択する。そこで，ユビキタス社会の基幹技術の一

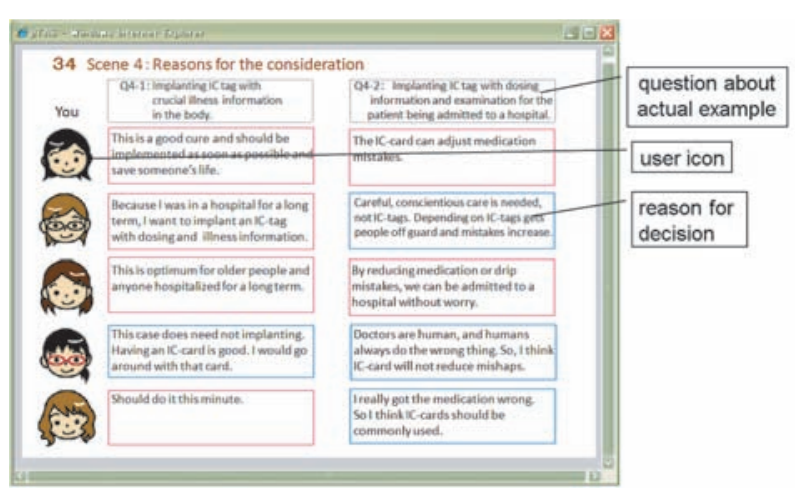

Fig. 4. Screen for browsing the reason for the decisions of others.

つとして期待され, 現在も多くの人が意識しないところで 用いているが，今後商品の個別管理などの社会のあらゆる 場面で用いられ，広く認知されることが期待される RFID 技術を選択する (24)。RFID は無線を使った個体識別技術 である。一般的に，人や物を管理するための ID などの情 報を記録するメモリ (RFID タグ), タグと無線で通信する リーダ・ライタ，IDに関連付けられた情報を記録するデー 夕ベースなどから構成される。RFID 技術は, 社会導入が 実現した場合の社会的影響の大きさから, 利用に対し否定 的な意見も多いため, 導入, 研究・開発の方針に関して, 一 般の人々が意見を表明する意義が高い。

また, RFIDについて一般の人々の意見を聞くために, イ メージのしやすさを考慮して 16 問の質問（導入事例）が 作成されている ${ }^{(25)}$ 。様々な観点から, RFID が社会に導入 された場面が設定されている。その場面は一般の人々がイ メージしやすい 5 つの生活場面に区分されている。場面 1 は家電量販店での RFID の利用, 場面 2 は特定の人（犯罪 者）に対するRFIDの利用, 場面 3 はデパートでの利用, 場面 4 は医療現場での利用, 最後にその他の場面として場 面 5 という形で区分している。本研究では, RFID の具体 的な導入・利用事例として, この質問を利用し, 意見表明 を行ってもらう。この質問は全部で 16 問あるが, 色々な観 点を知ってもらうために, 16 問全てについて意見を表明し てもらう。そのために, 場面ごとに質問をまとめた上で, $\langle 3 \cdot 4\rangle$ で示した意見表明のプロセスを複数回繰り返す。

$\langle\mathbf{4} \cdot \mathbf{1} \cdot \mathbf{2}\rangle$ 予備実験 システムの動作確認や人数や時 間の設定を調整のために，予備実験を行った（1グループ 5 人, 計 30 人)。その結果, 5 人で利用するシステムは滞 りなく利用された。また，実験参加者に行ったアンケート の結果, 全体の $73 \%$ の参加者 (22 人) が 5 人が適切であ ると回答し， $13 \%$ (4 人) が 6 人，5６人，5７人が適切 であると回答した。そのため, 同時に意見表明を行う人数 は 5 人に決定した。各プロセスの時間は微調整を繰り返し, ユーザの評価が高い時間を選択した。最終的な時間設定は, 1 つの質問ごとに, 「賛成・反対の判断」,「他者の判断を閲 覧」が約 10 秒,「判断理由の記述」が約 1 分,「他者の判断 理由を閲覽」が約 40 秒とした。 
$\langle\mathbf{4} \cdot \mathbf{1} \cdot \mathbf{3}\rangle$ 実験参加者 1 グループ 5 名, 計 18 グルー プで実験を行う。一般性を持たせ，また様々な立場の人々 の多様な視点からの意見を得るために，20〜 59 歳の男女 90 名を対象とする。公共心のような心理意識は, 社会的立 場など様々な要因で差異が生じる ${ }^{(12)}$ 。今回の実験では一般 性を持たせることに重点を置き，他手法との比較は行わず， 全実験参加者に本システムを利用してもらう。

$\langle\mathbf{4} \cdot \mathbf{1} \cdot \mathbf{4}\rangle$ 手 順実用的な利用を想定し, 自宅か ら参加してもらう。各家庭のネットワークからシステムに アクセスして意見表明を行ってもらう。また，意見表明前 後にアンケートに回答してもらい，意見表明に関する考え などを主観的に評価してもらう。アンケートは主に 7 段階 評価 $(+3 \sim-3)$ や自由記述で行う。事前・事後アンケー 卜は, チェックボックスなどを用いた一般的なネット調査 の形式で行う。システムの操作方法は, 事前アンケートの 後にマニュアルページを用意し, 説明する。問題が発生し た場合は，電話で対応する。

\section{$\langle 4 \cdot 2\rangle$ 分析方針}

$\langle 4 \cdot 2 \cdot 1\rangle$ 意見の観点 まず，表明された意見の内容を 確認するために，質問ごとに意見の観点を分析する。どの ような観点からの意見があったかを賛成（A）と反対（D） に分けカウントする。一つの意見に多様な観点が含まれる ことが予想されるため, 重複を許可しカウントする。全参 加者の自由記述を一読した後, カテゴリーを抽出し, 分類 するという流れを用いる。

$\langle\mathbf{4} \cdot \mathbf{2} \cdot \mathbf{2}\rangle$ 公共心の活性化次に, 公共心の活性化に 関して調査し，提案手法が心理面に与えた影響を調査する (アンケート 1)。そのために, RFIDの観点から「重要性 認知」と「責任感」が実験前後で変化したかをそれぞれ評 価する。比較のために，科学技術の観点から調査する。重 要性認知は, 利他的行動が必要とされる問題が存在するこ とを認知することである $(\langle 2 \cdot 2 \cdot 3\rangle)$ 。具体的な生活場面を テーマとしているため, ここでの問題は自分の生活への影 響の大きさに相当する。さらに, それに対して求められる 利他的行動は意見表明に取り組むことに相当する。以上よ り,「生活への影響」の有無を感じるか否か, 意見表明をす る意思があるか否かを調査する。

また，責任感は，利他的行動を行うという自分の責任を 意識することである $(\langle 2 \cdot 2 \cdot 3\rangle)$ 。そこで，単に意見表明に 取り組む意思を持っているというだけではなく，それを実 際に行えるか否かを調査する。さらに，単純に意見表明を 行える能力を有しているという意味ではなく, 問題に対し 高い意識を持った上で，取り組めるのかを確認するために， 「興味・関心」の有無を調査する。以上より, 実験前後で科 学技術と RFID について「興味・関心があるか」,「生活へ の影響があると思うか」,「意見表明したいと思うか」,「意見 表明できると思うか」の 4 つの項目に 7 段階 $(+3 \sim-3)$ で回答してもらう。アンケート項目ごとに実験前後, 及び 科学技術と RFIDの差を評価する。

\section{$\langle 4 \cdot 2 \cdot 3\rangle$ 手法の特徵に対する評価 次に, 手法の特}

徵が実験参加者に与える影響について評価する。提案手法 では，利便性や双方向性を制限した意見表明の場を提供し ている。利便性を制限するのは，公的な場のように他者の 目を意識させることにある。双方向性の制限により，他者 とのコミュニケーションを制限する中で他者の意見を知る ことができるようにしている。そこで，これらの制限が意 見表明に取り組む姿勢にどのように影響するかを実験後に アンケートで調査する（アンケート 2)。アンケートの項目 は, 今回の形式で他者の存在により「やる気がでたか」, 他 者の「意見は参考になったか」とする。他者の目が取り組 む姿勢に与える影響を 1 つ目の項目で確認し, 今回の形式 で他者の持っている意見を理解し得るのかを 2 つ目の項目 で確認する。7 段階評価の段階ごとの各割合を評価する。さ らに，意見を十分表明できたと感じられたかを実験後のア ンケートで調査する（アンケート 3 )。アンケートの項目は 「今回の形式で自分の意見を表明できたか」とする。そし て, その理由についても, 手法の特徴を選択する形式と自 由記述で調査する。選択肢は, 「知識の獲得」,「具体事例の 設定」,「賛成・反対の判断」,「時間の制限」,「意見の閲覧」, 「匿名性」,「パソコンの利用」とし，それ以外に要因があれ ば自由記述で挙げてもらう。7段階評価の段階ごとに各選 択肢の人数を評価する。

$\langle\mathbf{4} \cdot \mathbf{2} \cdot \mathbf{4}\rangle$ 参加者の基本的な意見傾向 最後に, 評価 実験を通し，参加者の基本的な考え方に変化があるかを調 査する（アンケート 4)。今回の提案手法では心理面への働 きかけを行っており，与える知識もこちらで選択している。 そのため, 参加者の考えを誘導してしまう可能性が危惧さ れる。そこで, RFIDの社会導入について「賛成」,「反対」, 「場合による」,「その他」という基本的な考えを評価実験前 後で調査する。同時に, 参加者の基本的な考え方が偏って いないかを確認し, 参加者の一般性を確認する。実験前後 で各選択肢の回答者数と回答の変化の仕方を評価する。ま た，実験後に自由記述で全体の感想を回答してもらう。

$\langle 4 \cdot 3\rangle$ 実験結果 評価実験の結果についてまとめる。

$\langle\mathbf{4} \cdot \mathbf{3} \cdot \mathbf{1}\rangle$ 意見の観点 一例として,「家電箱にタグが 埋め达まれる」という導入事例に対し得られた意見の一部 を以下に示す。

- 賛成 ; 「在庫管理の大幅な時間短縮と正確な数の把握は 現代では必須でしょう。間違いもさることながらお客 様に在庫はあるのときかれて即座にありますと回答さ れるのとお待ちくださいとったままなかなか返事がか えってこないのとでは買う意欲におおきな差が出てき ます。」

・賛成 ; 「購入後の箱についている IC タグから情報が漏 れないか気になるところはありますが，付いている情 報は商品情報くらいだろうからそれほど問題はないと 思います。在庫の数が正確に把握できたりして, 自分 の生活にもメリットがあると思います。」

・賛成; 説明されていたような在庫管理のほかにも, 棚 卸などの定期的で，時間のかかる作業にも役立つから。 
Table 1. Viewpoints in the expressed opinion (questions 1 - 16).

\begin{tabular}{|c|c|c|c|c|c|c|c|c|c|c|c|c|c|c|c|c|c|c|c|c|c|c|c|c|c|c|c|c|c|c|c|c|}
\hline & Q1 & & Q2 & & Q3 & & Q4 & & Q5 & & Q6 & & Q7 & & Q8 & & Q9 & & Q10 & & Q11 & & Q12 & & Q13 & & Q14 & & Q15 & & Q16 & \\
\hline & $\mathrm{A}$ & D & A & D & $\mathrm{A}$ & $\mathrm{D}$ & $\mathrm{A}$ & $\mathrm{D}$ & A & $\mathrm{D}$ & $\mathrm{A}$ & \begin{tabular}{|l|}
$\mathrm{D}$ \\
\end{tabular} & $\mathrm{A}$ & $\mathrm{D}$ & \begin{tabular}{|l|}
$\mathrm{A}$ \\
\end{tabular} & $\mathrm{D}$ & $\mathrm{A}$ & \begin{tabular}{|l|}
$\mathrm{D}$ \\
\end{tabular} & $\mathrm{A}$ & \begin{tabular}{|l|}
$\mathrm{D}$ \\
\end{tabular} & $\mathrm{A}$ & \begin{tabular}{|l|}
$\mathrm{D}$ \\
\end{tabular} & $\mathrm{A}$ & \begin{tabular}{|l|}
$\mathrm{D}$ \\
\end{tabular} & $\mathrm{A}$ & \begin{tabular}{|l|}
$\mathrm{D}$ \\
\end{tabular} & $\mathrm{A}$ & \begin{tabular}{|l|}
$\mathrm{D}$ \\
\end{tabular} & $\mathrm{A}$ & \begin{tabular}{|l|}
$\mathrm{D}$ \\
\end{tabular} & $\mathrm{A}$ & \begin{tabular}{|l|}
$\mathrm{D}$ \\
\end{tabular} \\
\hline V1 & 5 & 0 & 3 & \begin{tabular}{|l|l}
6 \\
\end{tabular} & 0 & 5 & 1 & \begin{tabular}{|l|}
1 \\
\end{tabular} & 0 & 18 & 2 & 9 & 3 & \begin{tabular}{|l|} 
\\
\end{tabular} & 2 & 12 & 2 & 7 & 0 & 8 & 0 & 6 & 0 & \begin{tabular}{|l|} 
\\
\end{tabular} & 0 & 1 & 1 & 5 & 0 & \begin{tabular}{|l|}
4 \\
\end{tabular} & 1 & 1 \\
\hline $\mathrm{V} 2$ & 90 & 0 & 58 & 3 & 0 & 0 & 0 & 0 & 0 & 0 & 40 & \begin{tabular}{|l|}
4 \\
\end{tabular} & 55 & 0 & 12 & 0 & 50 & 5 & 26 & 1 & 16 & 0 & 5 & 1 & 49 & 5 & 43 & 2 & 17 & \begin{tabular}{|l|}
4 \\
\end{tabular} & 34 & 3 \\
\hline V3 & 0 & 0 & 0 & 1 & 0 & 0 & 2 & 2 & 0 & 0 & 0 & 0 & 0 & \begin{tabular}{|l|} 
\\
\end{tabular} & 0 & 0 & 3 & \begin{tabular}{|l|}
17 \\
\end{tabular} & 1 & \begin{tabular}{|l|}
19 \\
\end{tabular} & 1 & 24 & 0 & \begin{tabular}{|l|} 
\\
\end{tabular} & 0 & 0 & 0 & 2 & 0 & \begin{tabular}{|l|l} 
\\
\end{tabular} & 12 & $\mid 19$ \\
\hline V4 & 0 & 0 & 23 & 1 & 43 & 1 & 56 & 3 & 0 & 0 & 0 & 0 & 0 & 0 & 0 & 0 & 0 & 0 & $\overline{0}$ & 0 & 0 & 0 & 0 & 0 & 0 & 0 & $\overline{0}$ & \begin{tabular}{|l|}
0 \\
\end{tabular} & 0 & \begin{tabular}{|l|l}
0 \\
\end{tabular} & 7 & 0 \\
\hline V5 & 19 & 1 & 5 & 0 & 0 & 1 & 0 & \begin{tabular}{|l|} 
\\
\end{tabular} & 0 & 1 & 0 & 0 & 0 & \begin{tabular}{|l|}
0 \\
\end{tabular} & 0 & 1 & 0 & 0 & 0 & \begin{tabular}{|l|}
0 \\
\end{tabular} & 0 & 0 & 1 & \begin{tabular}{|l|}
1 \\
\end{tabular} & 8 & 15 & 0 & 5 & 0 & \begin{tabular}{|l|}
9 \\
\end{tabular} & 0 & \begin{tabular}{|l|l|} 
\\
\end{tabular} \\
\hline V6 & 0 & 0 & 0 & 0 & \begin{tabular}{|l|l}
17 \\
\end{tabular} & 38 & 0 & \begin{tabular}{|l|}
6 \\
\end{tabular} & 1 & \begin{tabular}{|l|}
5 \\
\end{tabular} & 3 & 17 & 0 & 5 & 0 & 11 & 0 & 4 & 1 & 22 & 0 & \begin{tabular}{|l|}
16 \\
\end{tabular} & 0 & 46 & 1 & 8 & 1 & \begin{tabular}{|l|}
8 \\
\end{tabular} & 1 & 4 & 0 & 3 \\
\hline V7 & 0 & 0 & 0 & 4 & 1 & 2 & 6 & 22 & 0 & 68 & 0 & 28 & 0 & 24 & 0 & 51 & 0 & 16 & 0 & 24 & 0 & 41 & 0 & 46 & 0 & 9 & 0 & 21 & 0 & 56 & 0 & 11 \\
\hline V8 & 3 & 0 & 5 & 0 & 1 & 0 & 2 & 0 & 0 & 0 & 0 & 0 & 11 & 1 & 3 & 0 & 5 & $\begin{array}{ll}0 \\
\end{array}$ & 1 & 0 & 0 & 0 & 1 & 0 & 0 & 0 & 3 & \begin{tabular}{|l|}
0 \\
\end{tabular} & 7 & \begin{tabular}{|l|l}
0 \\
\end{tabular} & 6 & 1 \\
\hline V9 & 2 & 0 & 1 & 0 & 0 & \begin{tabular}{|l|}
0 \\
\end{tabular} & 0 & \begin{tabular}{|l|}
2 \\
\end{tabular} & 0 & 0 & 0 & 1 & 3 & 11 & 2 & 0 & 0 & 0 & 0 & \begin{tabular}{|l|}
0 \\
\end{tabular} & 0 & 0 & 0 & \begin{tabular}{|l|}
0 \\
\end{tabular} & 0 & 1 & 2 & \begin{tabular}{|l}
2 \\
\end{tabular} & 3 & \begin{tabular}{|l|l}
0 \\
\end{tabular} & 0 & \begin{tabular}{|l|}
0 \\
\end{tabular} \\
\hline V10 & 1 & 2 & 7 & 0 & 1 & 1 & 2 & \begin{tabular}{|l|}
1 \\
\end{tabular} & \begin{tabular}{|l|}
9 \\
\end{tabular} & 0 & 0 & 0 & 0 & \begin{tabular}{|l|}
0 \\
\end{tabular} & 7 & 1 & 3 & 3 & 4 & \begin{tabular}{|l|} 
\\
\end{tabular} & 0 & 3 & 0 & \begin{tabular}{|l|}
0 \\
\end{tabular} & 7 & 30 & \begin{tabular}{|l|}
19 \\
\end{tabular} & \begin{tabular}{|l|}
6 \\
\end{tabular} & 1 & 1 & 35 & 3 \\
\hline
\end{tabular}

ただし，出荷されるときには念のためタグをはずして 欲しいです。」

・反対；「全商品の箱に IC タグを埋め込めば，その箱は 消費者の元に行き，ゴミになる。毎回使い捨てにする にはもったいないと思うのだけれど…売れた商品から は取り外し，新たに入荷した商品に使い回しできるよ うなシステムなら賛成できる。」

・反対；「商品管理に手間がかからなくなることで, 職の 口が減るから。」

意見の観点の分類結果を Table 1 に示す。 $\mathrm{A}$ は賛成， D は反対を表す。観点は上から順に「V1：情報の問題」, 「V2： RFID の機能評価」,「V3：生態影響」,「V4：不正・犯罪防 止」, 「V5：金銭・人的コスト $」,\lceil\mathrm{~V} 6$ ：導入効果への疑問」, $\lceil\mathrm{V} 7$ : 不必要な導入」,「V8：自分の経験」,「V9：他用途の提 案」,「V10：その他」である。「V1：情報の問題」とは，プラ イバシーの侵害や情報の改ざん・不正使用などに言及して いる意見を表す。事例や賛否に関わらず，常に一定数の意 見の中に存在した。「V2: RFIDの機能評価」とは，RFID の利便性の高さや効率の良さなどに言及している意見を表 す。この観点も事例に関わらず，多くの賛成意見の中に存 在していた。「V3：生態影響」とは，RFIDの無線や身体へ の埋め込みなどによる影響に言及している意見を表す。医 療現場での事例において，RFIDによる医療の改善と悪影 響とを比較している意見が多く存在した。基本的には反対 意見の中に存在するが, 得られる利点の方が多いと判断し 賛成した人の意見の中に見られることもあった。「V4：不 正・犯罪防止」とは，RFIDのセキュリティ機能による不正 や犯罪の防止などに言及している意見を表す。防犯をテー マとしている場面 2 で多く見られた。「V5：金銭・人的コ スト」とは，RFIDの導入により得られる経済面の利益や 労働量の低減などに言及している意見を表す。労働量が減 少することで，商品の值下げなどの消費者（実験参加者） の利益につながることを期待する意見などがあった。「V6： 導入効果への疑問」とは，提示した事例にRFID を導入す ることで利益が得られるのか疑問に感じている意見を表す。 RFID 自体への疑問（精度など）のほか，提示した事例で RFID の機能を活用しきれるのかを問題視する意見などが あり，多くの事例の反対意見の中に存在した。「V7：不必
要な導入」とは，提示した事例にRFID を導入することに 全く意味がないと言及している意見を表す。場面 3 など生 活が少し便利になるといった事例に対し，『自分でできる』， 『機械に頼りたくない』といった意見が見られた。「V8：自 分の経験」とは, 実験参加者自身の経験を例として挙げて いる意見を表す。似た事例の中で利便性を体験したという 意見や提示事例のような状況を経験し苦労したという意見 などがあった。事例を問わず，常に少しずつ賛成意見の中 に存在した。「V9：他用途の提案」とは，提示事例において より効果的な RFID の活用法があると言及している意見を 表す。在庫管理と盗難防止を組み合わせる利用法や RFID で扱う情報の種類を変える提案などがあった。

上記観点の内，V1〜V5の 5 つの観点は RFID 技術の問 題点として現在よく挙げられている点である。一方, 残り の V6〜V10 は，参加者の経験や感情に基づく意見を含ん だ独自性の高い観点であった。すなわち, 現在 RFID の問 題とされている点を捉えた意見とそれ以外の参加者独自の 観点からの意見が表明されていた。このことから, 参加者 は問題を多角的に捉えた意見を表明しており，ある程度の 信頼性を持った意見が得られたと言え，同時に，個人の価 值観を把握できる意見であったとも言える。

$\langle\mathbf{4} \cdot \mathbf{3} \cdot \mathbf{2}\rangle$ 公共心の活性化 7 段階 $(+3 \sim-3)$ 評価の アンケート 1 の平均值を Fig.5, 標準偏差を Table 2 に示 す。実験前の段階では「興味・関心があるか」「生活への影 響があると思うか」という項目に関し，科学技術と RFID で有意な差が見られたほか（有意水準 $5 \%$ ), RFID は科学 技術に比べ全体に低い傾向が見られた。このことから，一 般の人々が通常時に有する萌芽的科学技術に関する公共心 は，公的な意識を持ちにくいとされている科学技術よりも さらに低いと考えられる。しかし, 実験後有意差はなくなっ ており，RFIDに関する公共心が活性化されていたと考え られる。また，RFIDに関して全ての項目で，実験前後で 有意な差が見られた（有意水準 $5 \%$ ）。科学技術に関しても， 「生活への影響があると思うか」以外の項目で，有意な差が 見られた（有意水準 $5 \%$ ）。このことから，提案手法による 意見表明を通し，RFIDのみならず科学技術に関する公共 心も活性化されたと考えられる。

$\langle\mathbf{4} \cdot \mathbf{3} \cdot \mathbf{3}\rangle$ 手法の特徵に対する評価Ｆig.6にアンケー 


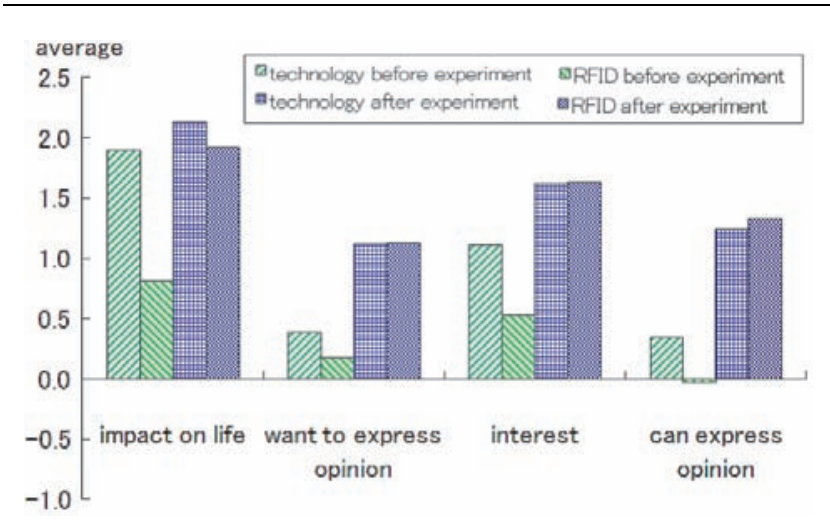

Fig. 5. Change of the view about technology and RFID.

Table 2. Standard deviation of view about technology and RFID.

\begin{tabular}{l|c|c|c|c|c}
\hline \multicolumn{2}{c|}{} & $\begin{array}{c}\text { impact } \\
\text { on life }\end{array}$ & $\begin{array}{c}\text { want to express } \\
\text { opinion }\end{array}$ & interest & $\begin{array}{c}\text { can express } \\
\text { opinion }\end{array}$ \\
\hline \multirow{2}{*}{ before } & technology & 1.0 & 1.3 & 1.4 & 1.6 \\
\cline { 2 - 6 } & RFID & 1.3 & 1.5 & 1.5 & 1.7 \\
\hline \multirow{2}{*}{ after } & technology & 0.9 & 1.3 & 1.2 & 1.5 \\
\cline { 2 - 6 } & RFID & 1.0 & 1.5 & 1.2 & 1.3 \\
\hline
\end{tabular}

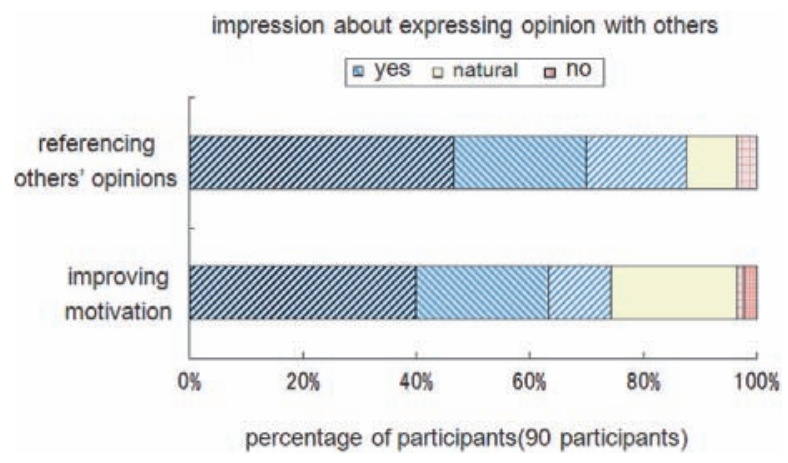

Fig. 6. Effect of limiting.

ト 2 の結果を示す。左から順に 7 段階中の $+3 \sim-3$ (斜 線部がなった，格子部分がならなかった）である。同時意 見表明という形式に関して，他の人の意見が参考になった と答えた人は 79 人 $(88 \%)$ で，意欲に繋がったという人は 67 人 $(74 \%)$ であった。このことから，一緒に意見表明に 取り組む他者の存在を意識できており，それが取り組む姿 勢に影響を与える可能性が示唆された。さらに, 他者の意 見を理解できるようになっていることが確認できた。

実験後の自由記述の感想でも制限に関する言及が見られ た。任意回答であったが，無回答者はおらず，90人の参加 者全員が何らかの回答をしていた。その中で，他の人の意 見が参考になったと述べた人は 45 人であった。また，同時 に行う人が存在することを評価していた人は 11 人，他者 の存在があることで取り組む姿勢が向上したと述べた人は 5 人であった。〈 $4 \cdot 3 \cdot 2\rangle$ の結果より，公共心が活性化された ことが示唆されているため, 今回加えた $2 つ の$ 制限が, 意 図通りに機能しており, 責任感の活性化に寄与していたと 考えられる。

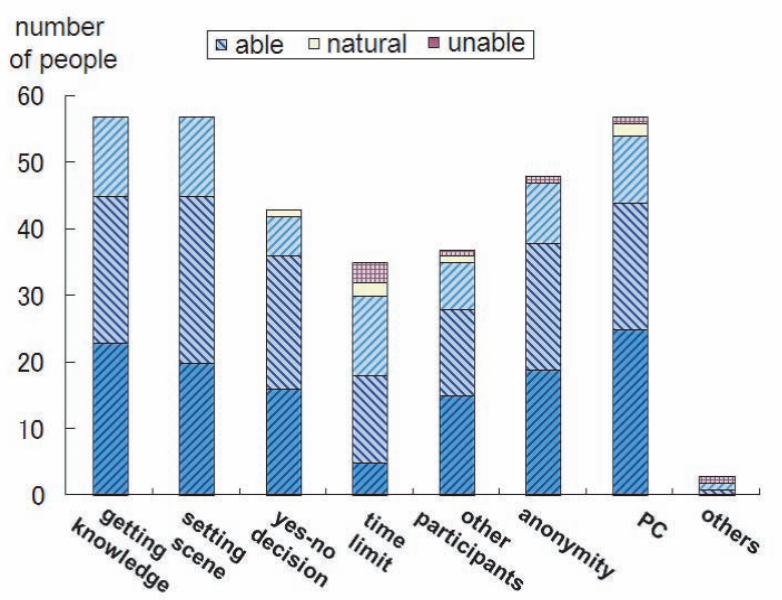

Fig. 7. Reasons for satisfying expressing opinion.

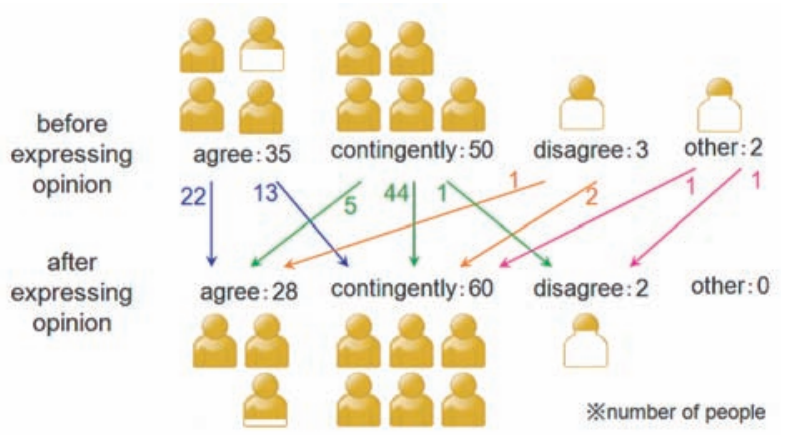

Fig. 8. Change of yes-no decisions before and after experiment.

アンケート 3 において，意見表明できたと答えた人は 83 人 $(92 \%)$ であった。これは非常に高い水準であり ${ }^{(26)}$, 提 案手法は意見表明のプロセスとして適切なものであったと 考えられる。その理由に関する解答を Fig.7 に示す。下か ら順に 7 段階中の $+3 \sim-3$ (斜線部ができた理由, 格子 部分ができなかった理由）である。萌芽的科学技術という テーマの性質上, 知識の獲得 (57 人) や具体的な導入 $\cdot$ 利 用事例（57 人）を理由として挙げる参加者が多かった。一 方，意見表明ができなかった理由として，時間の制限が挙 げられていた $(3$ 人)。これは, 短時間で意見をまとめるこ とが難しかったことが原因と考えられる。しかし，時間の 制限があったことを評価する意見も多く (30人)，逆に『時 間が長かった』、『短くて良かった』という意見も見られた (5 人)。また, コンセンサス会議などの長い時間を確保し ている手法に拉いても, 時間が足りないという意見は常に 見られる ${ }^{(3)}$ 。そのため, 万人が満足できる時間設定がある かどうかは今後も検討していく必要があると考えられる。 以上より, 提案手法が全体として, 意見表明のしやすさに 繋がっていると考えられる。

$\langle\mathbf{4} \cdot \mathbf{3} \cdot \mathbf{4}\rangle$ 参加者の基本的な意見傾向 アンケート 4 の結果を Fig.8 に示す。参加者のおおよその傾向が伺える が,「場合による」が多く，偏った性質を持っている様子は ない。「賛成」が多いとも見れるが，一般に自分に悪影響が 
あると思わない限りは，一般の人々は科学技術を特に否定 しないと言われているため，社会導入されていないRFID に対する意見としては妥当と言える ${ }^{(3)}$ 。また，参加者の多 くは，実験前後で考えを変化させていないことが分かった。 一番人数の多い変化は,「賛成」から「場合による」への変 化が 13 人であった。これは，様々な導入・利用事例を知っ たことによる変化と考えられる。また，実験前は分からな いという理由で「その他」と回答していた人がいたが，実 験後は全員が何らかの回答をしていることが確認できた。 以上のことから，提案手法は心理面に働きかけ，提供する 知識もこちらで選択したものだが，参加者の基本的な意見・ 思想に影響はしないことが予想される。

$\langle\mathbf{4} \cdot \mathbf{4}\rangle$ まとめ 評価実験の結果から, 提案手法に より，公共心が活性化され，その上で意見表明が行えるよ うになる可能性が示唆された。また，利便性や双方向性を 制限することの効果が示唆された。さらに, 知識の獲得や 具体的な導入事例など提案手法が全体として，意見表明の しやすさに好影響を与えたことが示唆された。一方で，時 間の制限に関してはさらなる検討が必要である。また，提 案手法が，実験参加者の考元・思想を変化させる危険性は 見られなかった。さらに，表明された意見の観点を見ると， RFID の問題点を捉えた意見と参加者独自の意見が表明さ れていることが示唆された。

\section{5. インターネット上の「ゆるやかなコミュニケー ション」}

インターネットを用いた意見表明では，対面型の意見表 明とは異なり，いつでも自由に意見が表明できることが特 徵である。しかし, 複雑な社会問題においては, 一般の人々 が自由に意見を表明することが難しいとされており，ある 程度決まった枠組みが必要とも言われている(27)。また，対 面型と比べて，分散型で表明された意見の信頼性が低いと されるのは，自由度が高すぎるからであり，対面型手法と 同じような枠組みで行うことが必要とも言われている(5)。 よって，提案手法により，公共心を有する意見が表明され たのは，インターネットの自由度の高さを意図的に限定し た点にあると考えられる。すなわち，参加者間で直接的な コミュニケーションを行わないようにして，間接的に他者 を意識させたこと (双方向性の制限)，その際にいつでも利 用できるというのではなく，決まった枠組み内でしか行え ないようにしたこと，さらに，参加者が自由に意見表明の 方法を選ぶのではなく，進行を統制し，決まった形式で意 見表明させたこと（利便性の制限）が，公共心の活性化に 繋がったと考えられる。インターネットの機能を制限する ことが，メリットとなり得ることを表す例として，今日の Twitter の流行も挙げられる。Twitter では，投稿文字数の 制限 (140 文字制限) が, 逆に, 利用者の気軽な情報発信と インフォーマルなコミュニケーションにつながっている。

機能制限により生じる限定的な参加者間のコミュニケー ションは，ある種のコミュニケーションの枠組みになって
いると考えられる。本研究では，公共心を有する意見表明 を目的に，比較的信頼性の高い意見が得られる公聴会など 対面形式の手法をもとに検討した結果として, 利便性と双 方向性という 2 つの性質に着目し, 制限をかけている。イ ンターネットには様々な特徴があるが, 「公共心を有する意 見表明手法」という観点のもとでは，この 2 つの性質が重 要な意味を持つと考えられる。実験結果として, 得られた 意見には，RFID の問題点を捉えた意見と参加者独自の意 見が存在し, また, 重要性認知や責任感の活性化も示唆さ れた。さらに，提案した手法（システム）の特徵が全体と して評価されていたことを考慮すると, 本研究の目的のも と加えた $2 つ の$ 制限は，目的を達成する上で効果的であり， また最低限度の条件であったと考えられる。

本研究では, 機能制限により生じるある種の枠組みを「ゆ るやかなコミュニケーション (Communication without explicit interaction)」という新たなコミュニケーションの枠 組みと位置づける。そして, これを実現する環境を提供し たことが, 評価実験で良好な結果が得られた重要な要因で あると考察する。分散環境で, 萌芽的科学技術を含む, 未 知で難解かつ重要なテーマに関して意見表明を行うときに は，ゆるやかなコミュニケーションという杵組みが，一般 の人々の心理面を変化させる助けになることが予想される。

以上で考察してきた「ゆるやかなコミュニケーション」 は，人々の間の意見交換を活発にさせるものではなく，逆 に制約を与える枠組みとなっている。すなわち, 参加者が 自分の投稿への感想や批判などに曝される懸念や，他者の 投稿に対して自分の考えを表明しなければならないという 懸念がなくなる。情報の流れとして一方向のコミュニケー ションとなり，他者との明示的なインタラクションを行わ ない。他者の存在は，人が社会を考える際に不可欠ではあ るが，明示的なインタラクションを行わないことで，負担 となる可能性をなくし, 意見表明という目的に際して, 適 切に他者の存在を適用したことが，本研究で生じた「ゆる やかなコミュニケーション」の効果であると考察される。

インターネットは, 「自由」な環境であるが，逆にその自 由が脅威となっており，社会的な場面にインターネットを 利用する際には丁寧な配慮が必要となる。本研究から導出 された「ゆるやかなコミュニケーション」は，その一つの 回答として利用可能な枠組みであり，社会的な意見表明が 必要な場面での活用が期待される。

\section{6. おわりに}

本研究では, 萌芽的科学技術の社会導入・利用に向けて, 一般の人々が公共心を有する意見を表明できる手法を，心 理面から検討し，提案した。そこで，インターネットの利 便性や双方向性を制限した意見表明の場を設計し，それを 用いた意見表明手法について検討した。また，提案手法の 効果を確認するために評価実験を行った結果, 提案手法に より, 公共心が活性化されている可能性が確認でき, 萌芽 的科学技術について一般の人々が公共心を有する意見表明 
が行える可能性が確認できた。

今後の課題としては, 提案手法の具体的な利用に向け, 適 切な意見を得るために必要となる人数や対象にできるテー マ, 得られる意見の具体的な活用方法などについて検討す ることが挙げられる。また，今回の評価実験で用いた質問の 観点と表明された意見の観点のさらなる検討を行い, RFID 以外の萌芽的科学技術に関してどのような事例を提示する ことが適当かを検討する必要がある。さらに，2つの制限 のもと実現されたゆるやかなコミュニケーションにより得 られる効果や他の参加型手法への活用可能性についても検 討していきたい。

(平成 22 年 7 月 2 日受付, 平成 22 年 12 月 1 日再受付)

\section{文献}

（1）山口富子・日比野愛子：「萌芽する科学技術 先端科学技術への社会 学的アプローチ」, 京都大学学術出版会 (2009)

（2）第 3 期科学技術基本計画，第 4 章社会·国民に支持される科学技 術 (2006)

（3） 小林傅司：「誰が科学技術について考えるのか一コンセンサス会議 という実験一」, 名古屋大学出版会 (2004)

（4） e-Gov:「電子政府の総合密ロイーガブ」, http://www.e-gov.go.jp/

（5）大隅 昇：「電子調查，その周辺の話題一電子的デー夕取得法の現 状と問題点—」, 統計数理, Vol.49, No.1, pp.201-213 (2001)

（6）仙台都市総合研究機構 Sendai Urban Research Forum：「市民の 声」の活用法に関する調查研究」, SURF 研究報告 (2003)

（7）舆論科学協会編：「世論調查の現状と課題」, 至誠堂 (1977)

（8）佐藤卓己：「世論の興論化」に向けて：戦後「世論」の成立史から」, 日本世論調查協会報, Vol.101, pp.34-37 (2008)

（9）高橋玲子・中込良廣：「原子力の国民的合意形成に向けた対話に関 する考察」，日本原子力学会和文論文誌，Vol.4, No.3, pp.177-186 (2005)

(10) B. S. Frey, F. Oberholzer-Gee, and R. Eichenberger: "The old lady visits your backyard: A tale of Morals and Markets", Journal of Economic Psychology, Vol.104, No.6, pp.1297-1313 (1996)

（11）佐伯 胖：「決め方の論理」，東京大学出版会 (1980)

(12) 藤井 聡：「社会的ジレンマの処方箋」, ナカニシヤ出版 (2003)

（13）金子暁嗣:「「公と私」に関する実験的研究：社会的ジレンマ事態にお ける集団規模の展開」，年報社会心理学、Vol.23, pp.85-114 (1982)

（14）岡田直之：「世論雑記：世論概念と世論調査」, 日本世論調查協会報, Vol.97, pp.58-61 (2006)

（15）川井良介：「世論とマス・コミュニケーション」，ブレーン出版 (1987)

(16) H. Schwarz: Normative influences on altruism, In: L. Berkowitz, Editor, Advances in experimental social psychology, Vol.10, Academic Press, New York, pp.221-279 (1977)

(17) M. Lynn and A. Oldenquist : "Egoistic and nonegoistic motives in social dilemmas", American Psychologist, Vol.41, No.5, pp.529-534 (1986)

（18） 久郷明秀 - 宇田旭伸 · 今木智隆 · 伊藤京子 ·下田 宏 · 若林靖永 吉川笨和：「WEB システムを使ったアフェクティブなリスクコミュ ニケーションモデルの開発と実験」,ヒューマンインタフェース学 会論文誌, Vol.7, No.4, pp.431-441 (2005)

（19）谷口綾子・島田敦子・高橋勝美・藤井 聡:「公共的問題に関する階層 的規範活性化モデルの提案一富士市に扔けるモビリティ・マネジメン 卜授業実践より一」, 土木計画学研究·講演集, Vol.31, pp.144-147 (2005)

（20）中川善典 :「ナノテクノロジーの社会的影響に関する問題の構造化」, 社会技術研究会, 社会技術研究論文集, Vol.4, pp.75-83 (2006)

（21）太田響子・林 裕子・松浦正浩・城山英明：「環境技術の社会導入 に関する政策プロセスにおける分野横断的ネットワークと公共的企 業家機能に関する分析〜埼玉県越谷市レイクタウンに扔ける住宅の 面的 $\mathrm{CO} 2$ 排出削減事業を事例として〜」, 社会技術研究会, 社会 技術研究論文集, Vol.5, pp.24-39 (2008)

（22）青木俊明・西野 仁・松井健一・鈴木 温: 「公共事業に掞ける情報 提示と態度形成」, 土木学会論文集, Vol.737, pp.223-235 (2003)

（23）田原敬一郎：「我が国の中央政府レベルにおける参加型政策分析の 普及・定着に向けた戦略一討議型世論調査を事例に一」, PI-Forum
誌, Vol.3 (2007)

（24）加瀬一郎監修, NTT コムウェア株式会社 研究開発部著：「RFID の現状と今後の動向」, 電気通信協会, pp.2-12 (2005)

２5）大阪大学コミュニケーションデザイン・センター:「平成 18 年度受 託研究報告書 ロボット社会実証実験のための外部評価の方法の確 立及びガイドラインの作成」, pp.175-248 (2007)

（26）佐々義子:「パブリックエンゲージメントを目指したサイエンスコミュ ニケーションの有効な手法の検討」，筑波大学博士学位論文 (2008)

（27） 福原知宏・松村憲一・村山敏泰・中野有紀子・西田豊明：「マルチ メディアプレゼンテーションシステムSPOC を用いた社会問題に 関する情報提供とウェブログを用いた情報発信に関する実駼報告」, 社会技術研究会，社会技術研究論文集，Vol.4，pp.177-188 (2006)

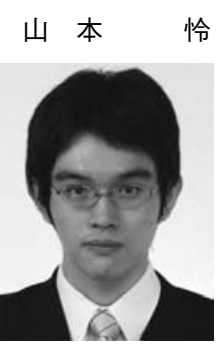

（非会員） 1986 年生。 2009 年 3 月大阪大学基 礎工学部システム科学科卒業。2009 年 4 月同大 学大学院基礎工学研究科に入学。2010 年同学に 所属。

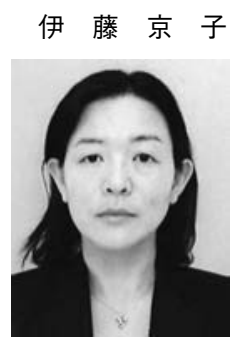

(非会員) 1999 年 3 月京都大学工学部電気電子 工学科卒業。2001 年 3 月同大学大学院エネルギー 科学研究科修士課程修了。2004 年 3 月同博士課 程修了。同年 4 月大阪大学大学院基礎工学研究科 助手。2005 年 4 月同大学コミュニケーションデ ザイン・センター助手 (基礎工学研究科兼任)。現 在, 同助教。ヒューマンインタフェースなどの研 究に従事。博士 (エネルギー科学)。情報処理学 会, 計測自動制御学会各会員。

大 西 智 士 (非会員) 2007 年 3 月大阪大学基礎工学部シス

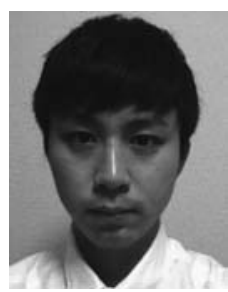
テム科学科卒業。2009 年 3 月同大学大学院修士 課程修了。2009 年 4 月より (株) 毎日放送勤務。

西 田 正 吾 （フェロー） 1974 年 3 月東京大学工学部電子工学

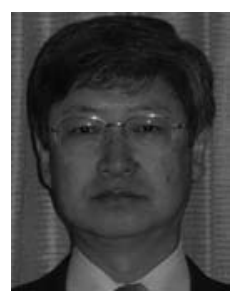
科卒業。1976 年 3 月同大学大学院修士課程修了。 同年 4 月三菱電機（株）入社。同社中央研究所シ ステム基礎研究部研究員, グループマネージャー を経て, 1995 年 4 月大阪大学基礎工学部システ 厶工学科教授。その後, 大阪大学大学院基礎工学 研究科システム創成専攻教授。現在，大阪大学副 学長。システム技術, ヒューマンインタフェース 技術の研究に従事。1984 年-1985 年 MIT メディアラボ客員研究員。 工学博士。ヒューマンインタフェース学会論文賞 (2001 年, 2005 年), 電気学会業績賞（2004 年）, 同論文賞（1986 年, 1993 年）等受賞。 電子情報通信学会, 情報処理学会, IEEE ほか会員。IEEE Fellow。 電子情報通信学会フェロー。 